\title{
Bacterial PCR in the diagnosis of joint infection
}

\author{
J Jalava, M Skurnik, A Toivanen, P Toivanen, E Eerola
}

\begin{abstract}
Objectives-To evaluate the value of broad range bacterial PCR in the diagnosis of joint infection and to find out if there are bacteria causing arthritis which are not cultivable by the present methods.

Methods-Polymerase chain reaction (PCR) with broad range bacterial primers and DNA sequencing (bacterial PCR) was used to analyse 154 synovial fluid (SF) samples from patients with different arthritic diseases.

Results-Bacterial DNA was detected in 18 SF samples, including samples from six patients with culture proven purulent arthritis, and from three patients with possible purulent arthritis. Three samples from patients with culture confirmed purulent arthritis remained negative in bacterial PCR.

Conclusions-The results indicate that in the usual diagnostic laboratory setting bacterial PCR does not offer any obvious advantage over bacterial culture in the microbiological diagnosis of joint infection.
\end{abstract}

(Ann Rheum Dis 2001;60:287-289)

Bacterial joint infection is a serious problem, the outcome of which depends on appropriate treatment. Arthrocentesis and synovial fluid (SF) analysis are crucial for the proper diagnosis. To obtain microbiological diagnosis Gram staining and aerobic and anaerobic bacterial cultures of the SF are important. However, there are situations when both these methods fail. ${ }^{1}$ Polymerase chain reaction (PCR) applying broad range bacterial primers and combined with DNA sequencing (bacterial PCR) is a method which can be used to amplify and analyse genes coding for ribosomal RNA (16S rDNA) of most bacterial species. Bacterial PCR has been successfully used for microbiological diagnosis in various infections (endocarditis, intra-amniotic infections, and meningitis) when bacterial culture has failed..$^{2-4}$ In the present work we wanted to study the value of bacterial PCR in the diagnosis of joint infection. We had two goals: firstly, to find out if there are bacteria causing arthritis which are not cultivable by the present methods and, secondly, to find joint infections where bacterial cultures fail to detect normally cultivable bacteria because, for example, of antibiotic treatment.

\section{Materials and methods}

SAMPLES

One hundred and fifty four SF samples from 133 patients representing different arthritic diseases were analysed. All samples were taken for normal bacterial diagnostics, and were retrospectively used for bacterial PCR. The samples were stored at $4^{\circ} \mathrm{C}$ for not more than two weeks before use in PCR. Ninety three of the samples were clinical swabs (charcoal or calcium alginate swabs immersed in SF) and 61 were SF samples. Clinical diagnosis of the patients who were culture and/or bacterial PCR positive was confirmed afterwards.

DETECTION OF BACTERIA AND BACTERIAL DNA

Bacteria were isolated and identified by standard procedures used in clinical microbiology. Both aerobic and anaerobic primary cultures were done.

For DNA isolation SF samples (500-1000 $\mu \mathrm{l})$ were centrifuged at $15000 \mathrm{~g}$ for 10 minutes to collect cells. The cell pellets were resuspended in $500 \mu$ l of sterile water or sterile phosphate buffered saline. The swabs were first shaken with 100-200 $\mu$ l sterile water to collect SF cells and bacteria. DNA was extracted and purified as described previously. ${ }^{5}$

PCR and sequencing primers have been described previously. ${ }^{3}$ For bacterial DNA amplification a hot start PCR was performed using AmpliWax PCR Gems (Perkin-Elmer, Norwalk, CT) according to the manufacturer's instructions. The total reaction volume was 50 $\mu \mathrm{l}$, containing $5 \mu \mathrm{l}$ of the sample, 1.25 units of AmpliTaq DNA polymerase LD (PerkinElmer), $12.5 \mathrm{pmol}$ of each primer, $0.2 \mathrm{mmol} / 1$ of each deoxyribonucleoside triphosphates (Promega Co, Madison, WI), $3.5 \mathrm{mM} \mathrm{MgCl}_{2}$, $25 \mathrm{ng} / \mathrm{ml}$ 8-methoxypsoralen (Sigma Chemical Co, St Louis, MO), 1\% DMSO (Merck, Darmstadt, Germany), $10 \mathrm{mM}$ Tris- $\mathrm{HCl}(\mathrm{pH}$ 8.3), and $50 \mathrm{mM} \mathrm{KCl}$. The PCR consisted of 35 cycles $\left(94^{\circ} \mathrm{C}\right.$ for 15 seconds, $55^{\circ} \mathrm{C}$ for 15 seconds, $72^{\circ} \mathrm{C}$ for 30 seconds). The cycling was preceded by a one cycle denaturation step $\left(95^{\circ} \mathrm{C}\right.$ for one minute) and followed by a one cycle extension step $\left(72^{\circ} \mathrm{C}\right.$ for seven minutes). PCR was performed using a Perkin-Elmer GeneAmp PCR System 9600. The analytical sensitivity of the bacterial PCR was determined using serial dilutions of Escherichia coli cells. Two series were prepared: one with $E$ coli cells alone and one with $E$ coli cells and $10^{5}$ human leucocytes. DNA from the dilutions was extracted similarly to the SF samples, and bacterial PCR was performed as described above. Detection and sequencing of the PCR products were carried out as described earlier. ${ }^{34}$ Both DNA strands of the region between positions 533 and 907 of bacterial 16S rRNA ( $E$ coli numbering) were sequenced. Sequence comparison with a local reference database was done as described previously. ${ }^{5}$ 
Table 1 Comparison of culture, DNA sequence analysis, and clinical diagnosis

\begin{tabular}{|c|c|c|c|c|c|}
\hline Patient & Sample & Culture & PCR/sequence analysis & $\begin{array}{l}\text { \% Identity/length of } \\
\text { overlap }(b p)\end{array}$ & Diagnosis/comment \\
\hline 1 & Cells & Staphylococcus aureus & Staphylococcus sp. & $100 / 301$ & Purulent arthritis, prosthetic joint, rheumatiod arthritis, sepsis \\
\hline 2 & Cells & Escherichia coli & Enterobacter $\mathrm{sp} .^{\star}$ & $100 / 359$ & Purulent arthritis, diabetes mellitus, joint operation, sepsis \\
\hline 3 & Swab & Staphylococcus aureus & Staphylococcus sp. & $100 / 360$ & Purulent arthritis, sepsis \\
\hline 4 & Swab & Streptococcus gordonii & Streptococcus sanguis & $99.45 / 361$ & Purulent arthritis, prosthetic joint, rheumatoid arthritis \\
\hline 5 & Cells & Viridans streptococcus & Streptococcus gordonii & $99.65 / 287$ & Purulent arthritis, intra-articular injection \\
\hline 6 & Swab & Streptobacillus moniliformis & Streptobacillus moniliformis & $99.45 / 359$ & Purulent arthritis, two month history of infection \\
\hline 7 & Swab & Staphylococcus epidermidis & - & - & Purulent arthritis, prosthetic joint \\
\hline 8 & Cells & Staphylococcus epidermidis $\dagger$ & - & - & Purulent arthritis, prosthetic joint \\
\hline 9 & Swab & Aeromonas hydrophila & - & - & Purulent arthritis, gout \\
\hline 10 & Cells & Escherichia coli & - & - & Trauma, culture contamination \\
\hline 11 & Cells & - & $\neq$ & - & Possible purulent arthritis, prosthetic joint \\
\hline 12 & Cells & - & $\neq$ & - & Possible purulent arthritis, prosthetic joint \\
\hline 13 & Swab & - & Staphylococcus sp. & $100 / 259$ & Possible purulent arthritis, unclear \\
\hline 14 & Cells & - & Staphylococcus sp. & $95.50 / 191$ & Reactive arthritis triggered by salmonella \\
\hline 15 & Cells & - & $\ddagger$ & - & Trauma \\
\hline 16 & Swab & - & Bacillus sp. & $97.80 / 350$ & Stress injury \\
\hline 17 & Cells & - & Chloroplast $16 \mathrm{~S}$ rDNA & $97.24 / 282$ & Chronic osteomyelitis \\
\hline 18 & Cells & Staphylococcus aureus & Staphylococcus sp. & $99.72 / 362$ & Not known \\
\hline 19 & Swab & Staphylococcus aureus & Staphylococcus sp. & $99.73 / 363$ & Not known \\
\hline 20 & Cells & Staphylococcus aureus & Staphylococcus sp. & $99.69 / 326$ & Not known \\
\hline 21 & Swab & Staphylococcus aureus & Staphylococcus sp. & $100 / 360$ & Not known \\
\hline 22 & Swab & Staphylococcus epidermidis & - & - & Not known \\
\hline 23 & Swab & Staphylococcus aureus & - & - & Not known \\
\hline 24 & Swab & Staphylococcus aureus & - & - & Not known \\
\hline 25 & Swab & - & Acinetobacter junii & $100 / 362$ & Not known \\
\hline
\end{tabular}

^Several enterobacterial species (Echerichia coli, Shigella boydii, Shigella dysenteriae, Shigella flexneri, Shigella sonnei).

†Bacterial culture from synovial fluid was negative but Staph epidermidis was cultured from a synovial biopsy specimen. Bacterial PCR was not performed from the biopsy specimen.

$\ddagger$ Based on overlapping sequences, it is possible that DNA from more than one bacterial species may exist in the sample.

ๆSeveral different chloroplast $16 \mathrm{~S}$ rDNAs.

SPECIAL LABORATORY TECHNIQUES

Special precautions were taken to avoid bacterial DNA contamination and carry over contamination. Methods for preventing carry over contamination have been described previously. ${ }^{5}$ Ultraviolet irradiation (four minutes, 366 nm, Hanau Fluotest) together with 8-methoxypsoralen was used for destruction of bacterial DNA in the PCR reagent mixture before addition of the sample, as described previously. ${ }^{6}$ As a quality control of the samples and the DNA extraction, the presence of human DNA was studied by amplifying part of the human $\beta$ globin gene. ${ }^{5}$

\section{Results}

Altogether 154 SF samples were analysed. Nineteen were negative for $\beta$ globin PCR, indicating that they contained components that inhibit PCR or that the DNA in the samples was degraded. Of the remaining 135 samples, 25 were positive by culture and/or bacterial PCR (table 1). The clinical diagnosis was available only in 17 of these cases. For the remaining eight cases the clinical diagnosis was not obtained owing to insufficient information submitted by the healthcare centres and municipal hospitals. From 14 patients, more than one sample was available. Except for samples from patients 1,13 , and 15, all these samples were negative in bacterial culture and bacterial PCR. From patient 1, two samples were taken. The first sample was positive in culture and bacterial PCR, and the second sample taken 11 days later, negative in both. From patients 13 and 15 one sample was positive in bacterial PCR and negative in bacterial culture and other samples were negative by both methods.

\section{Discussion}

This work was carried out to study whether bacterial PCR can be used to analyse SF sam- ples taken for a diagnostic purpose. We also wanted to determine if there are bacteria causing arthritis which are not cultivable. Unfortunately, the material used was not as representative as it might have been because the samples were analysed retrospectively and clinical data were not always fully available.

In theory, the sensitivity of broad range bacterial PCR should be better than that of bacterial culture because bacteria can contain more than one rRNA gene. ${ }^{7}$ However, in practice this is not true. The detection limit of one gene can hardly be achieved because all reagents used in PCR and DNA extractions contain bacterial DNA. ${ }^{8}$ The volume of specimen used in bacterial cultures is larger than that used in PCR. Isolation of DNA from Gram positive bacteria might not be efficient. ${ }^{5}$ The analytical sensitivity of our bacterial PCR was 60 or five $E$ coli cells depending on whether human cells were present or not. However, we had at least three patients with purulent arthritis and negative bacterial PCR. In two of these, bacterial cultures from SF were positive. This result indicates that in practice the diagnostic sensitivity of bacterial PCR does not match that of bacterial culture.

In our study three patients (Nos 11-13) were initially suspected to have purulent arthritis. Bacterial PCR was positive but bacterial cultures remained negative in all these cases. PCR results with DNA from multiple bacteria species are not convincing from the diagnostic point of view and could represent contaminations. Of the two samples taken simultaneously from patient 13, only one was positive for Staphylococcus sp. The clinical diagnosis and value of these PCR findings remain unclear.

All DNA polymerases and other reagents used in PCR and DNA isolation contain bacterial DNA. ${ }^{6}$ We used special precautions to prevent carry over contamination and to 
destroy contaminating bacterial DNA from the PCR reagents. Also the Taq polymerase used was known to contain a smaller amount of bacterial DNA than other Taq polymerases. However, our material included at least five cases (4\%) which were false positives (Nos 14-17 and 25). One reason for this might be the retrospective nature of our study. Even though special precautions were taken to exclude contamination during the PCR, the samples were originally taken for normal bacterial cultures and during that process and the storage, no special precautions were taken to avoid contamination. Our results, together with the high number of false positives reported in other studies,${ }^{9}{ }^{10}$ reflect problems which might arise when bacterial PCR is used for the diagnosis of (joint) infections. The possibility of contamination has to be kept in mind when results are interpreted.

Results from the sequence analysis agreed relatively well with the results from the bacterial culture (table 1). We applied only partial $16 \mathrm{~S}$ rDNA sequences in the sequence analysis. These short DNA sequences are obtained easily and they have also a proven usefulness in the diagnosis of infections, ${ }^{3}$ though they do not always allow bacterial identification at the species level, sometimes not even at the genus level. This is understandable considering that sequencing of the whole $16 \mathrm{~S}$ rDNA is not always enough for exact bacterial identification. ${ }^{11}$

All bacteria causing arthritis recovered in this study by bacterial PCR can be considered to be normally growing, readily identifiable micro-organisms. This result is congruent with other studies dealing with reactive arthritis, ${ }^{9}$ undifferentiated arthritis, ${ }^{10}$ and rheumatoid arthritis, ${ }^{12}$ where new uncultivable bacteria have not been found. In addition, we have recently analysed $45 \mathrm{SF}$ samples taken for a diagnostic purpose, and all bacteria identified with PCR were easily cultivable in vitro. ${ }^{5}$ So with the available data, we can conclude that most of the bacteria causing arthritis are cultivable by the present methods and that normal bacterial culture is sufficient for bacterial diagnosis. However, there are a few exceptions, of which Lyme arthritis is the most important. ${ }^{13}$ Although Borrelia species grow in the laboratory, they have seldom been cultured from joint specimens. The same is true in cases of venereal arthritis triggered by Chlamydia trachomatis $^{14}$ or Neisseria gonorrhoeae. ${ }^{15}$ In these situations PCR with species specific primers has proved to be a useful complementary tool to obtain the final diagnosis.

We are grateful to Anne Peippo and Tiina Haarala for their excellent technical assistance and to Dr Olli-Pekka Lehtonen for excellent technical assistance and synovial fluid samples. We also thank Dr Kaisu RantakokkoJalava for helpful comments on the manuscript. This work was
supported by the Academy of Finland and EVO of the Turku supported by the Acad
University Hospital.

1 Toivanen A, Toivanen P. Aetiopathogenesis of reactive arthritis. Rheumatology in Europe 1995;24:5-8.

2 Jalava J, Kotilainen P, Nikkari S, Skurnik M, Vänttinen E, Lehtonen OP, et al. Use of the polymerase chain reaction and DNA sequencing for detection of Bartonella quintana in the aortic valve of a patient with culture-negative infective endocarditis. Clin Infect Dis 1995;21:891-6.

3 Jalava J, Mäntymaa ML, Ekblad U, Toivanen P, Skurnik M, Lassila O, et al. Bacterial 16S rDNA polymerase chain reaction in the detection of intra-amniotic infection. $\mathrm{Br} \mathrm{J}$ Obstet Gynaecol 1996;103:664-9.

4 Kotilainen P, Jalava J, Meurman O, Lehtonen O-P, Rintala $\mathrm{E}$, Seppälä O-P, et al. Diagnosis of meningococcal meningitis by broad range bacterial polymerase chain reaction assay of cerebrospinal fluid. J Clin Microbiol 1998;36:2205-9.

5 Rantakokko-Jalava K, Nikkari S, Jalava J, Eerola E, Skurnik M, Meurman O, et al. Direct amplification of rRNA genes in diagnosis of bacterial infections. J Clin Microbiol 2000; in diagno

6 Meier A, Persing DH, Finken M, Böttger EC. Elimination of contaminating DNA within polymerase chain reaction reagents: implications for a general approach to detection of uncultured pathogens. J Clin Microbiol 1993;31:64652 .

7 Kunst F, Ogasawara N, Moszer I, Albertini AM, Alloni G, Azevedo V, et al. The complete genome sequence of the gram-positive bacterium Bacillus subtilis. Nature 1997; 390:249-56

8 Tanner MA, Goebel BM, Dojka MA, Pace NR. Specific ribosomal DNA sequences from diverse environmental settings correlate with experimental contaminant. Appl Environ Microbiol 1998;64:3110-13.

9 Nikkari S, Merilahti-Palo R, Saario R, Söderström K-O, Granfors K, Skurnik M, et al. Yersinia-triggered reactive arthritis. Use of polymerase chain reaction and immunocytochemical staining in the detection of bacterial components from synovial specimens. Arthritis Rheum 1992;35:682-7.

10 Wilbrink B, van der Heijden I, Schouls LM, van Embden JD, Hazes JM, Breedveld FC, et al. Detection of bacterial DNA in joint samples from patients with undifferentiated arthritis and reactive arthritis, using polymerase chain reaction with universal $16 \mathrm{~S}$ ribosomal RNA primers. Arthritis Rheum 1998;41:535-43.

11 Stackebrandt E, Goebel BM. Taxonomic note: a place for DNA-DNA reassociation and 16S rRNA sequence analysis in the present species definition in bacteriology. Int J Syst Bacteriol 1994;44:846-9.

12 Gray J, Marsh PJ, Walker DJ. A search for bacterial DNA in RA synovial fluid using polymer chain reaction. Br J Rheumatol 1994;33:997-8.

13 Nocton JJ, Dressler F, Rutledge BJ, Rys PN, Persing DH, Steere AC. Detection of Borrelia burgdorferi DNA by polymerase chain reaction in synovial fluid from patients with Lyme arthritis. N Engl J Med 1994;30:229-34.

14 Nikkari S, Puolakkainen M, Yli-Kerttula U, Luukainen R, Lehtonen O-P, Toivanen P. Ligase chain reaction in detec-
tion of chlamydia DNA in synovial fluid cells. Br J Rheumatol 1997;36:763-5.

15 Muralidhar B, Rumore PM, Steinman CR. Use of the polymerase chain reaction to study arthritis due to Neisseria gonorrhoeae. Arthritis Rheum 1994;37:710-17. 